\title{
小型飛行体へのマイクロ波無線給電システム*1 Microwave Wireless Power Supply System to a Micro Aerial Vehicle
}

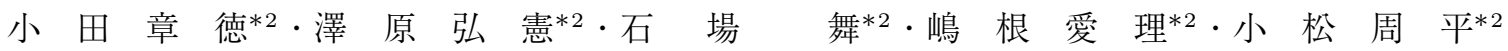 \\ Akinori Oda, Hironori Sawahara, Mai Ishiba, Eri Shimane, Shuhei Komatsu,

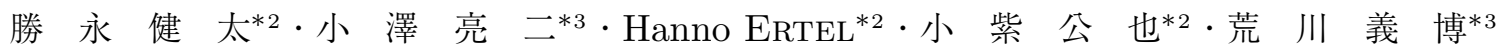 \\ Kenta Katsunaga, Ryoji Ozawa, Hanno Ertel, Kimiya Komurasaki and Yoshihiro Arakawa
}

Key Words : Wireless Power Transmission, Microwave, Active Phased Array, Micro Aerial Vehicle

\begin{abstract}
A microwave power beaming system was developed to realize wireless power supply to a Micro Aerial Vehicle. This system consists of transmitting, tracking, and receiving systems. In the transmitting system, a $5.8 \mathrm{GHz}$ microwave beam was irradiated from an active phased array antenna. Transmitting power was $4 \mathrm{~W}$ and the beam divergence angle was $9 \mathrm{deg}$. In the tracking system, a $2.45 \mathrm{GHz}$ pilot signal was detected by a two-dimensional tracking antenna and the position was deduced though the software retro-directive function. The maximum tracking error was $1.97 \mathrm{deg}$ in the azimuth direction and $1.79 \mathrm{deg}$ in the radial direction. In the receiving system, a light-weight flexible patch rectenna was developed using felt pad as substrate. The maximum rectenna efficiency of $45.3 \%$ was obtained with a $100 \Omega$ road at $63 \mathrm{~mW}$ input power. By integrating these systems, auto-tracking wireless power supply was demonstrated to a MAV model circling at the altitude of $1,500 \mathrm{~mm}$. As a result, a motor was kept rotated. Received power was $24.3 \mathrm{~mW}$ at maximum and $17.6 \mathrm{~mW}$ on average and the total transmission efficiency was estimated at $0.60 \%$.
\end{abstract}

\section{記号の説明}

$D:$ 送電アンテナアレー径

$d_{1}:$ 送電アンテナ間隔

$d_{2}:$ 追尾アンテナ間隔

$E:$ 電界

$h:$ 送電アンテナ開口面からの高さ

$r:$ 旋回半径

$t:$ 時間

$V_{\text {out }}:$ 出力信号電圧

$\alpha$ : パイロット信号入射角

$\alpha_{\mathrm{azi}}$ : アジマス方向誤差

$\alpha_{\mathrm{rad}}:$ ラジアル方向誤差

$\theta$ : 旋回角

$\theta_{\mathrm{div}}:$ 送電ビーム発散角

$\theta_{\text {ste }}:$ 送電ビームステアリング角

$\eta:$ 主ローブに含まれる電力割合

$\lambda$ : 波長

\section{1. は じめに}

災害地の偵察・監視や，体内の検診などを目的としたマ イクロロボットは, 近年の $\mathrm{mW}$ レベルの電力で動作する IC, センサ, モータ, LED 等の出現により, より高機能な

\footnotetext{
*1 (C) 2011 日本航空宇宙学会

平成 23 年 3 月 30 日原稿受付

*2 東京大学大学院新領域創成科学研究科先端エネルギー工学専攻

*3 東京大学大学院工学系研究科航空宇宙工学専攻
}

設計が可能となってきている。これらはバッテリ駆動を想 定しているが，駆動時間とバッテリ質量はトレードオフの 関係にあり長期間の作動は見込めない，一方，有線で電力 を供給しようとすると, 線の重みで動けなくなるサイズで あったり，線を引きずっては進めない場所に展開されるも のであったりする，従って，これらの電力を無線で供給す ることができればマイクロロボットの用途が広がる.

マイクロ波ビームを用いた無線給電技術は, 宇宙太陽発 電衛星から地球への送電 ${ }^{1,2)}$ や, モバイル PC や携带電話, 電気自動車への給電 ${ }^{3)}$ など，様々な用途に応用 4,5$)$ が試み られて打り，本研究ではこの技術を三次元空間を移動する マイクロ飛行体への無線給電システム ${ }^{6)}$ へ適用することを 試みる.

\section{2. マイクロ波ビームを用いた無線給電システム}

2.1 システムの概要 本研究で開発するマイクロ波ビー ムを用いた移動体への無線給電システムの概略を第 1 図に, 地上システムの写真を第 2 図に示す。本システムでは特に 移動体を捕捉，追尾し，そこへビームを正確に指向させる 技術が重要となる。

送電システムの上空を旋回するマイクロ飛行体（Micro Aerial Vehicle) が発するパイロット信号を, 地上の複数の 追尾アンテナが受信し，その信号の位相のずれから到来方 向を特定するレトロディレクティブ方式を用いている. 得 られた位置情報はアクティブフェーズドアレイを用いた送 電システムに送られ，マイクロ波のデジタル位相制御によっ てビーム形成㧍よび指向を行う。移動体側では薄型軽量レ 


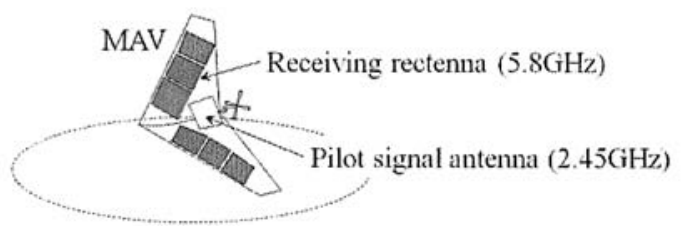

Tracking antenna $(2.45 \mathrm{GHz})$

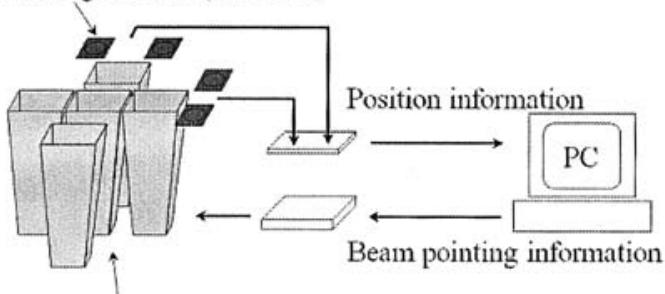

Transmitting antenna $(5.8 \mathrm{GHz})$

第1図 マイクロ波無線給電システム全体の概念図

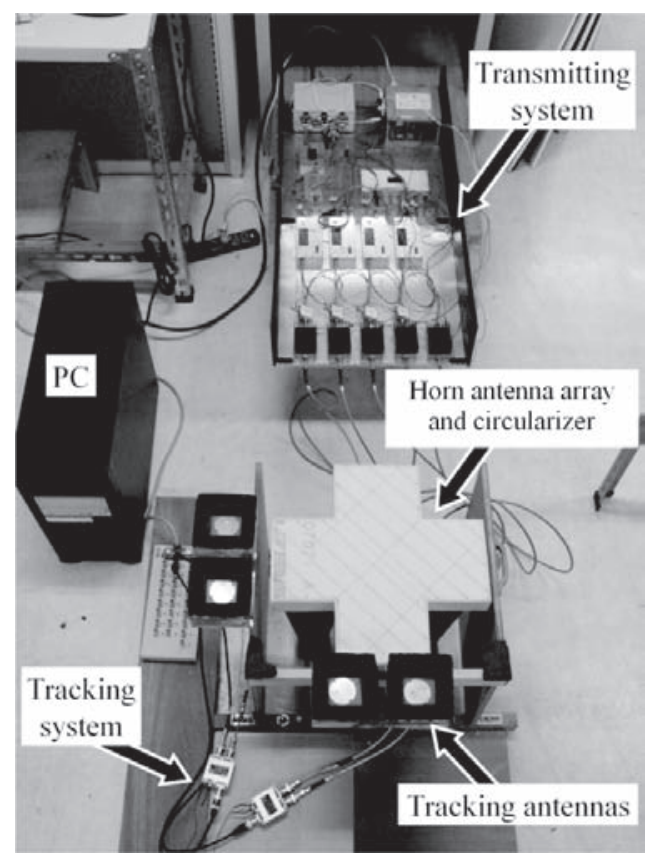

第 2 図 地上側システムの写真

クテナ（整流機能付きアンテナ）によってマイクロ波を受電 するとともに，直流電流に変換してプロペラの駆動に用い る。電力送電には $5.8 \mathrm{GHz}$ ，パイロット信号には $2.45 \mathrm{GHz}$ のマイクロ波を用いる.

2.2 送電システム 正確かつ素早いビーム制御を可能 にするため, 送電システムにはアクティブフェーズドアレ イアンテナを採用している7)，そのブロック図を第 3 図に 示す．アンテナを機械的に指向させる方法とは異なり，マ イクロ波の位相制御によりビームの形成，指向を行うため, 大きな設備に抢いても慣性の制約を受けることなく，より 高速なビーム指向が可能となる.

まず主発振器において $5.8 \mathrm{GHz}$ のマイクロ波を発生させ, 分配器によって 5 系列に分ける. 最も左側の列を基準とし,

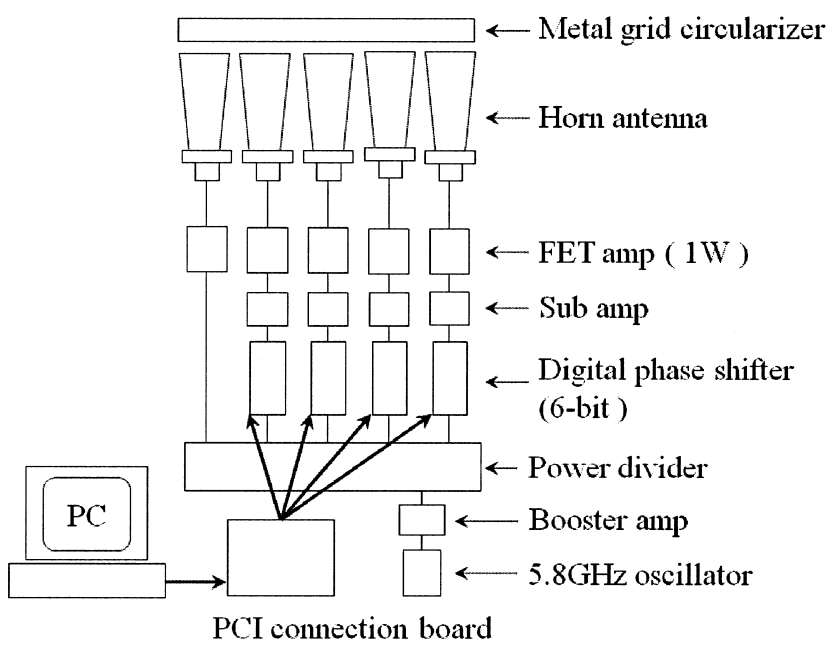

第 3 図 送電システムのブロック図

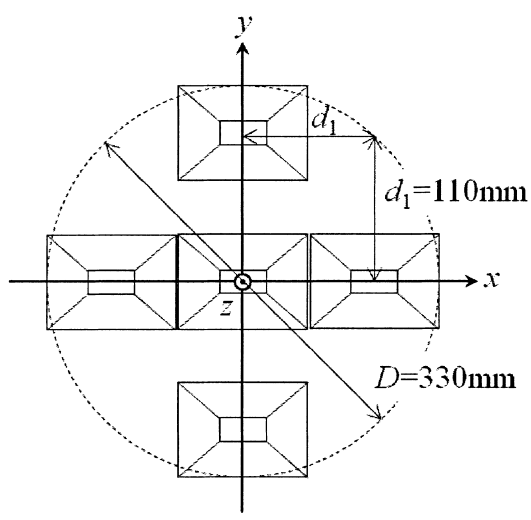

第 4 図＼cjkstart送電用アンテナアレイの配置

残りの各列において 6 ビットデジタル移相器によって必要 な位相を加える。 そして，サブアンプによりデジタル移相 器に伴う電力損失を補い, 電界効果トランジスタアンプに よって各列の電力をそれぞれ $1 \mathrm{~W}$ に揃え, $1 \mathrm{~m}$ の同軸フレ キシブルケーブルを経て送電用方形ホーンアンテナに送っ ている。電力測定の結果，フレキシブルケーブルでの損失 が約 $1 \mathrm{~dB}$ （約 $20 \%$ ）であり，放射される電力は合計 $4.0 \mathrm{~W}$ である。アンプをアンテナに直接接続すれば，この損失は 無くすことができる.

ホーンアンテナアレイの配置を第 4 図に示す。ビームの 発散角 $\theta_{\text {div }}$ とアンテナ径 $D$ は (1) 式のように反比例の関 係があるため, 大きな開口を用いると指向性が高まるが, 逆 に最大ステアリング角 $\theta_{\text {ste, } \max }$ （主ローブとグレーティン グローブの大きさが同じになる角）は (2) 式のようにアン テナ間隔 $d_{1}$ （アンテナ中心間の距離）と反比例の関係があ り，間隔が広がるとステアリング角が小さく制限される。

$$
\begin{aligned}
& \theta_{\text {div }}=\arctan (2 \lambda / \pi D) \\
& \theta_{\text {ste } \max }=\arcsin \left(\lambda / 2 d_{1}\right)
\end{aligned}
$$

僅か 5 つのアンテナ要素で 2 次元のビーム形成抢よび指向 を実現するため, アンテナ間隔を $d_{1}=110 \mathrm{~mm}$ ，アンテナ 


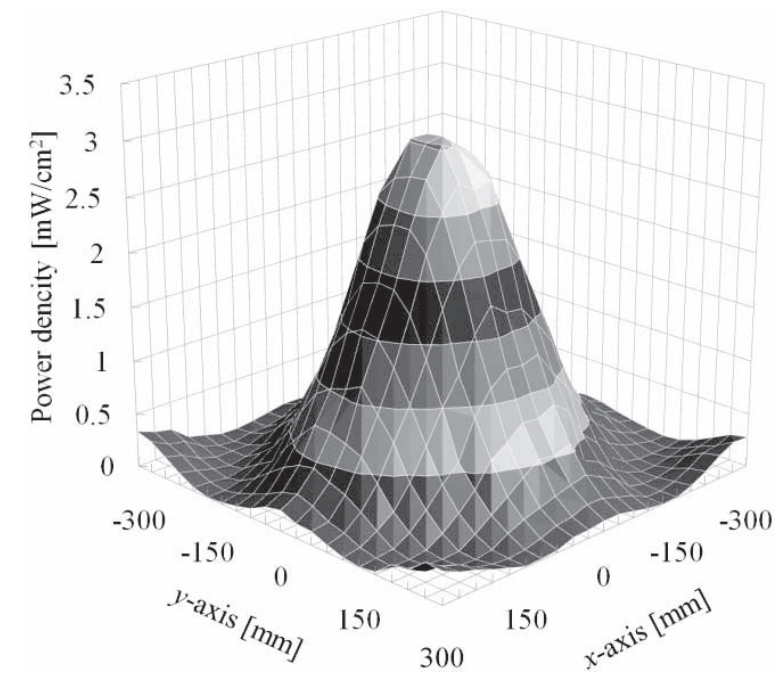

第 5 図 放射電力密度分布測定結果

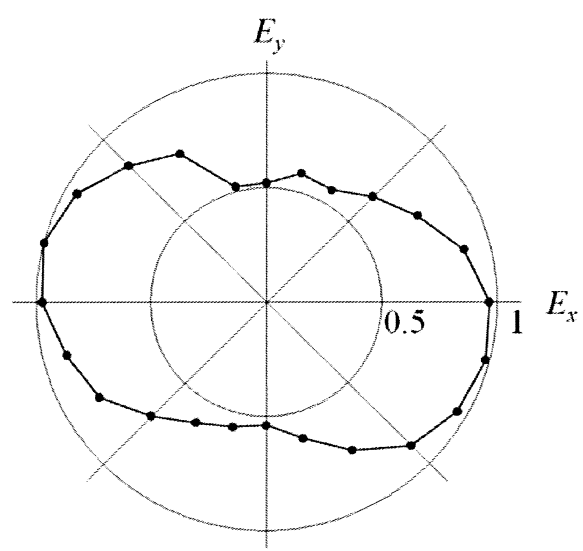

第 6 図 送電波偏波形状の測定結果

直径を $D=330 \mathrm{~mm}$ とし, ビーム発散角 $9 \mathrm{deg}$, 最大ステ アリング角 $12 \mathrm{deg}$ を実現している.

さらに, MAVのヨー角は時々刻々と変化するため, 偏 波方向に依存しない円偏波による送受電を行う必要がある. そこで方形ホーンアンテナから放射される直線偏波を円偏 波に変換する金属グリッド型サーキュラライザ8)を設計製 作し，ホーンアンテナアレイ開口部に装着した。

第 5 図に高さ $1,500 \mathrm{~mm}$ に扔ける放射ビームの電力密度 の測定值, 第 6 図に偏波性能の測定値を示す. 複数のアン テナから放射されるマイクロ波が空間で合成され，ビーム 品質 $M^{2}=1.6$, 発散角 $9 \mathrm{deg}$ のガウシアンビームを形成 することができている，偏波は完全には円偏波となってい ない.

アンテナ間隔がマイクロ波の波長 $51.7 \mathrm{~mm}$ よりも大きい ので, サイドローブの他にグレーティングローブが生じる. 特にステアリング角を大きくとると, グレーティングロー ブが相対的に大きくなり，主ローブに含まれる電力の割合 が低下する (第 7 図)。この関係より，抄よそ有効なビーム ステアリング角は拉よそ $9 \operatorname{deg}$ であると考えられる.

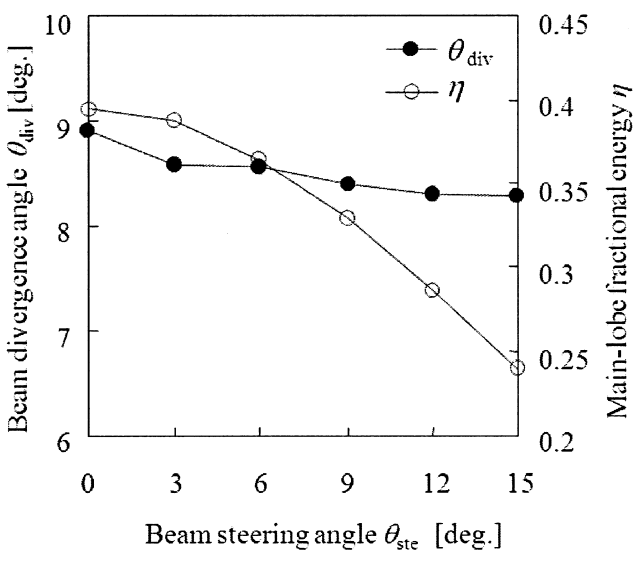

第 7 図 ステアリング角と主ローブのビーム発散角拉よび主ローブに 含まれる電力割合の関係（数值シミュレーション結果）

Pilot signal $(2.45 \mathrm{GHz})$

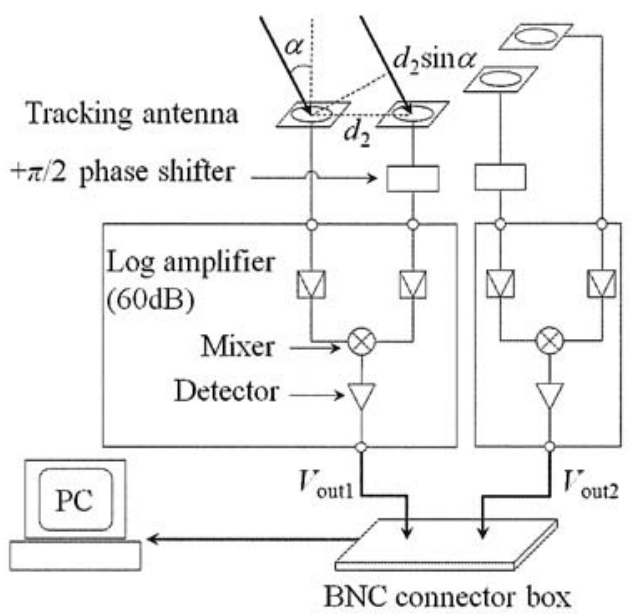

第 8 図 追尾システムのブロック図

2.3 追尾システム 旋回する MAV の追尾には位相比 較法によるソフトウェアリトロディレクティブ方式を採用 した，そのブロック図を第 8 図に示す，MAV 側から送信さ れた $2.45 \mathrm{GHz}$ のパイロット信号を，地上 $(x-y$ 平面)に二 次元配列された 2 対の追尾アンテナで受信する，対になっ たアンテナのうち一方の受信波に位相差 $90 \mathrm{deg}$ を加え, 利 得の高いログアンプで増幅することで電圧振幅を合わせた 後, ミキサーにより合成している. 2 つ波が同位相の場合 は強め合い, 逆位相の場合は弱め合う。この合成波を整流 して得られた電圧值から， $x$ 軸方向， $y$ 軸方向それぞれに ついての信号入射角を LabVIEW を用いて算出する，各ラ インのコンポーネント誤差も LabVIEW プログラム内で修 正できるため, 精度の高い追尾が可能である，追尾アンテ

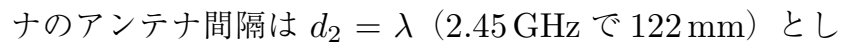
た。これにより，パイロット信号入射角が $-12 \mathrm{deg} \leqq \alpha \leqq$ $12 \mathrm{deg}$ の範囲で, 入射角と出力信号值の関係は第 9 図に示 すような 1 対 1 の対応をとる。つまり，この範囲であれば 入射角を推定できる。

MAV に搭載するパイロット信号アンテナには, 当研究 


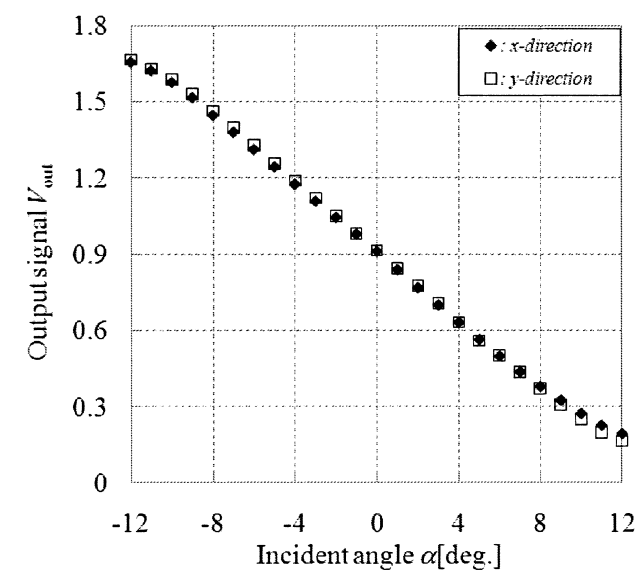

第 9 図 パイロット信号入射角と合成波の出力信号值

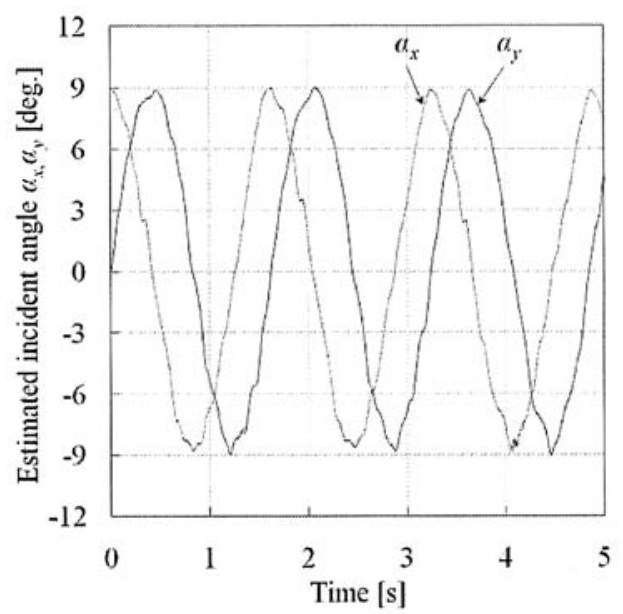

第 10 図 推定された入射角 $\alpha_{x}, \alpha_{y}$ の時間変化

高度 $h=1,500 \mathrm{~mm}$, 旋回半径 $r=237 \mathrm{~mm}$, 周期 $1.62 \mathrm{sec}$.

室で設計した薄型軽量円偏波パッチアンテナを，追尾用ア ンテナには JRC 社製作の円偏波パッチアンテナを用いた. MAVを模擬したパイロット信号発信装置を用いて，旋回 するターゲットの二次元追尾実験を行った，追尾アンテナ の上空 $h=1,500 \mathrm{~mm}$ の高さにおいて, $2.45 \mathrm{GHz}$ 発振器 付きアンテナを旋回半径 $r=237 \mathrm{~mm}$, 回転周期 $1.62 \mathrm{sec}$ （モー夕回転速度 $\omega=37.0 \mathrm{rpm}$ ）で旋回させた. この条件 での最大入射角は $9 \mathrm{deg}$ である。計測で得られた出力信号 から推定された入射角の時間変化を第 10 図に示す。振幅が $\alpha= \pm 9 \mathrm{deg}$ で周期が $1.62 \mathrm{sec}$ であることから，パイロッ 卜信号を正しく追尾できていることがわかる.

第 10 図で得られたデー夕を元に, 追尾システムの精度 を評価した。実際の MAV モデルの位置と算出された位置 との誤差を, ラジアル方向およびアジマス方向 (第 11 図), それぞれに対し原点を中心とした角度で算出した，結果は

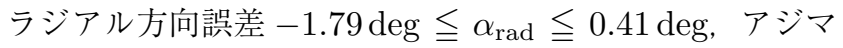
ス方向誤差 $-1.97 \mathrm{deg} \leqq \alpha_{\text {azi }} \leqq 0.47 \mathrm{deg}$ となった．送電 ビーム発散角 $\theta_{\mathrm{div}}=9 \mathrm{deg}$ を考慮すると, 十分な精度であ ることがわかる。

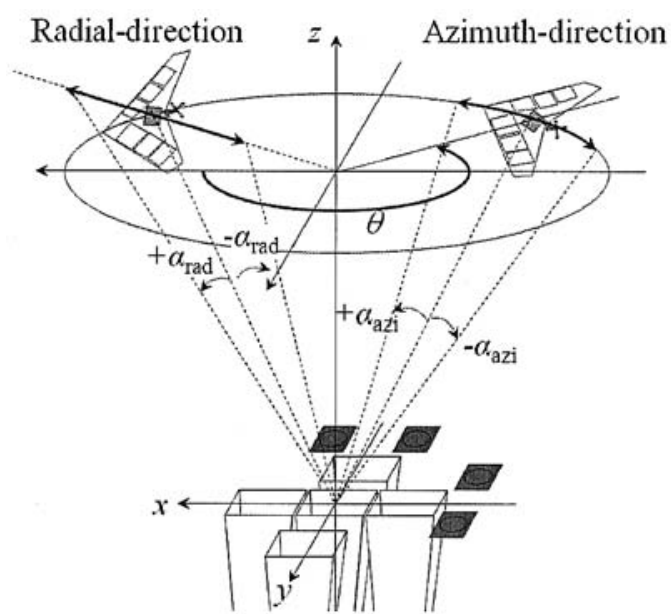

第 11 図 自動追尾実験の概略図
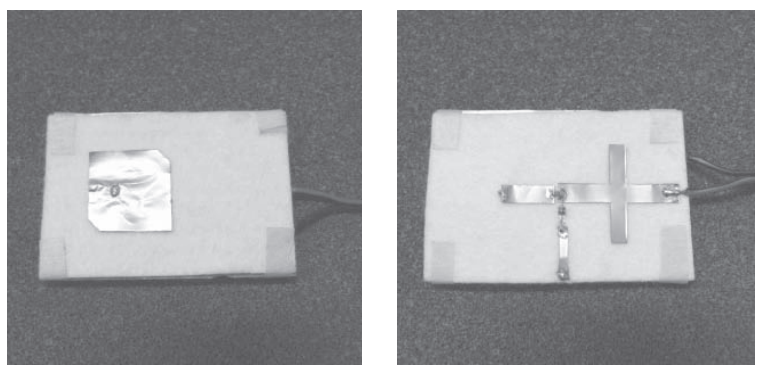

第 12 図＼cjkstart軽量フレキシブルレクテナ

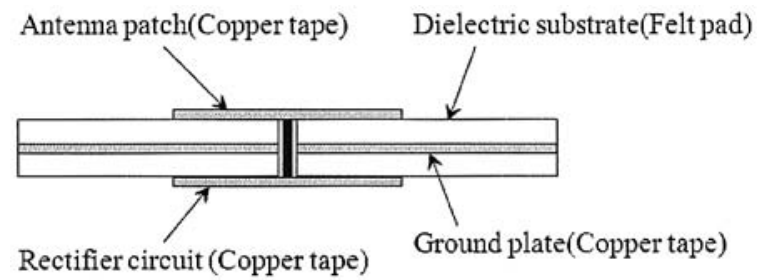

第13図 レクテナの構造

2.4 受電システム 照射されたマイクロ波ビームを受 電し直流電力を得るため, 軽量フレキシブルレクテナを開 発した。アンテナにはマイクロストリップパッチ円偏波ア ンテナを用いた。一般に, 誘電体基板にはエポキシ等の硬 い材料が用いられるが, 本レクテナでは市販のフェルト材 を用い, アンテナパッチと地板およびマイクロストリップ ラインには銅箔テープを用いることによって, 軽量化とフ レキシブル化を実現した。 フェルト材の厚さは約 $1 \mathrm{~mm}$ で, スペクトルアナライザーを用いて測定したアンテナ放射の 周波数特性から推定した比誘電率は 1.003 である。開発し たレクテナの写真を第 12 図に示す. 左側はアンテナ面であ り，右側は整流回路面である。地板は 2 枚のフェルト材に 挟まれており，第 13 図に示すようなサンドウィッチ構造に なっている。

ホーンアンテナからレクテナに照射される電力が $13.2 \mathrm{~mW}$ のときの, 負荷抵抗とレクテナ効率, 出力電圧 の関係を第 14 図に示す。この電力は JRC 社製パッチアン 


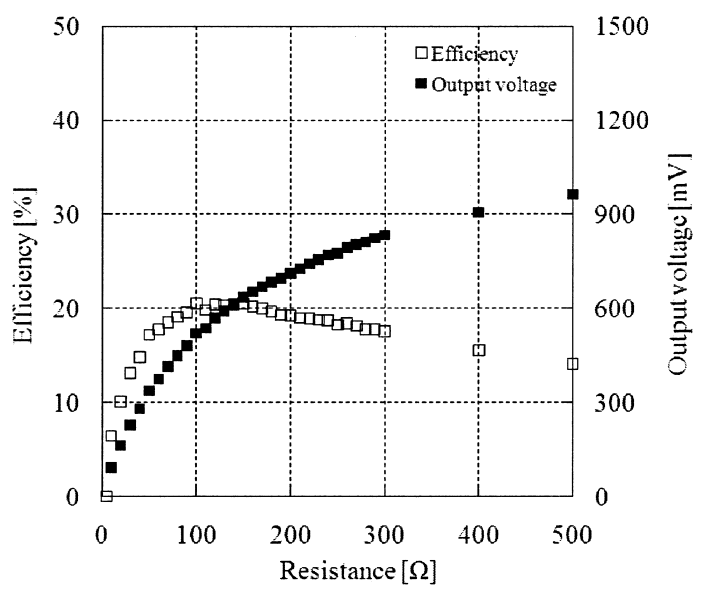

第 14 図 レクテナ効率, 出力電圧と負荷抵抗の関係 マイクロ波入力電力 $13.2 \mathrm{~mW}$.

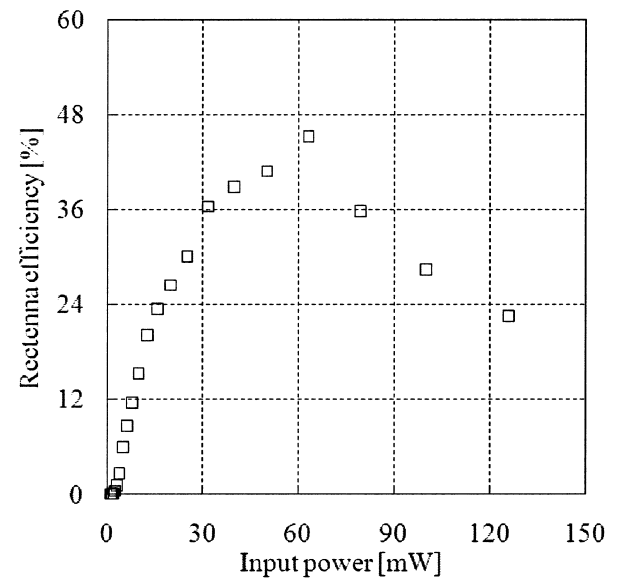

第 15 図 レクテナ効率の入力電力依存性 負荷抵抗 $100 \Omega$.

テナとマイクロ波パワーメータによって校正している。図

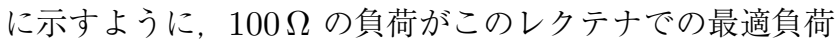
であり, 最適負荷は入力電力を変えても変わらない

第 15 図は最適負荷 $(100 \Omega)$ において, ホーンアンテナ からの距離を変化させて入力電力を変化させたときのレク テナ効率である. 効率は入力電力の増加にともない上昇し, $63 \mathrm{~mW}$ で最大効率の $45.3 \%$ 迎える。低電力域で効率が 低いのは，ダイオードの立ち上がり電圧分だけ整流できて いないためである。一方 $63 \mathrm{~mW}$ 以上で急に効率が低下す るのは，ダイオードの耐圧を超えたためであると考えられ る。まだ整流回路に反射損失やジュール損失が存在するが, 数十 $\mathrm{mW}$ レベルのマイクロ波をさらに高い効率で整流する には，それに適したダイオードの開発が効果的である。

\section{3. システムの統合とデモンストレーション}

送電・追尾・受電システムを統合し，旋回する MAV モ デルへの自動追尾送電のデモンストレーションを行った. レクテナを搭載した MAV モデルの写真を第 16 図に示す. $\mathrm{MAV}$ モデルには最小作動電力 $1 \mathrm{~mW}$ ，負荷抵抗 $10 \Omega$ の

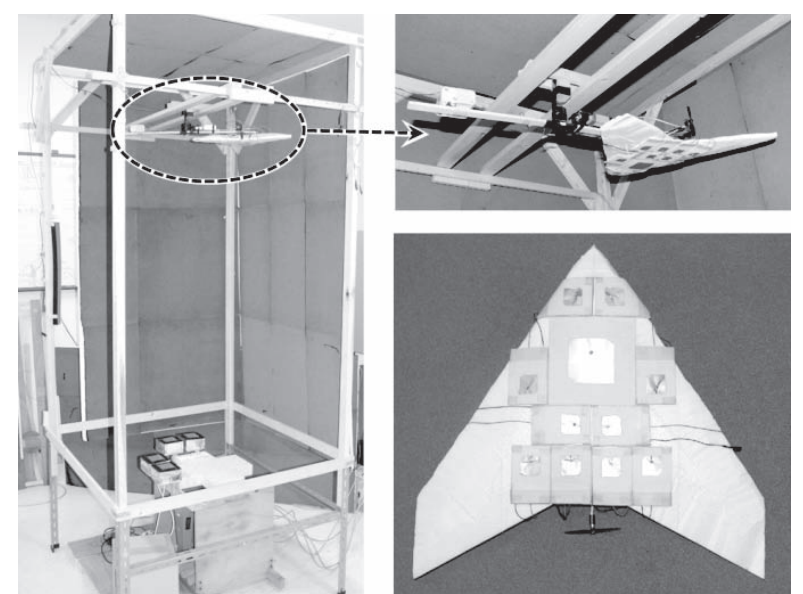

第 16 図 送電デモンストレーション実験系 (左), MAV モデル（右 上)，翼下面に配置されたレクテナアレイ（右下）

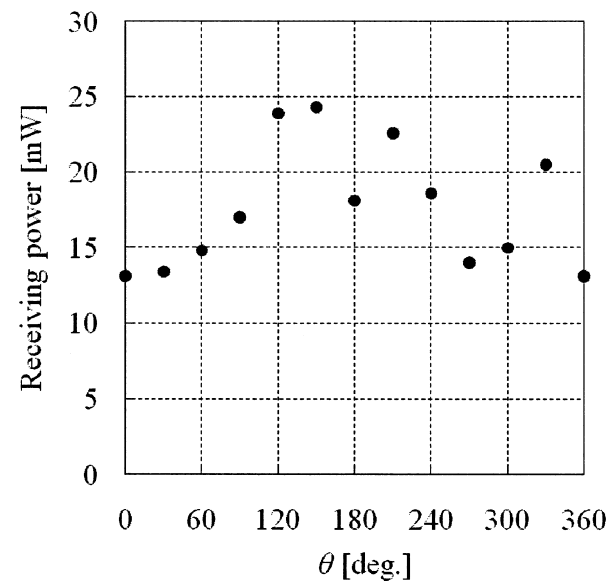

第 17 図 旋回時の受電電力 負荷抵抗 $10 \Omega$

プロペラ付き小型モータを取り付けた。 しかし自力では飛 行できないため，サポーティングバーに取り付け，それを モータで回転させ旋回させている.

翼下面にはレクテナ 10 素子を並列接続することにより， モータとのインピーダンスマッチングを行っている. アン テナアレイのピッチを変えて測定したところ最適ピッチは $0.85 \lambda$ (= $44 \mathrm{~mm})$ であった。このときのアンテナ 1 個当 たりの有効面積は $1,930 \mathrm{~mm}^{2}$ である.

第 16 図右下写真にある翼面中央の大きなアンテナはパ イロット信号送信用の $2.45 \mathrm{GHz}$ 円偏波パッチアンテナで ある。

デモンストレーションは, MAV モデルを $h=1,500 \mathrm{~mm}$, $r=237 \mathrm{~mm}$ の条件で，いろいろな速度で旋回させながら 伝送実験を行った。このときビームステアリング角は $9 \mathrm{deg}$ である。その結果，どのような条件でもプロペラは回転を 続けた。

同じ実験系を用いて受電電力の測定を行った．負荷抵抗 は $10 \Omega$ を用い, その結果を第 17 図に示す。受電電力は位 置により上下はあるものの, 最低 $13.2 \mathrm{~mW}$, 最大 $24 \mathrm{~mW}$, 平均 $17.6 \mathrm{~mW}$ の電力を得ることができた，位置によって受 
電電力が異なっているのは，送電波やレクテナにまだョー 角依存性があるためである。さらに，第 15 図に示したよう に, レクテナ効率は入力電力の変化に敏感であり, ヨー角 依存によるレクテナへの入力電力の変化が受電電力に増倍 されて影響したものである。

本システムの伝送効率を評価すると, 送電電力 $4.0 \mathrm{~W}$ に対し受電電力は最大 $24 \mathrm{~mW}$ であるから, 総合伝送効率 は $0.60 \%$ 程度である。 その内訳は，ビームステアリング角 $9 \mathrm{deg}$ のきき主ローブに含まれる電力が放射された電力の約 $33 \%$ で, $h=1,500 \mathrm{~mm}$ で主ローブの面積は $173,000 \mathrm{~mm}^{2}$ であるのに対し，アンテナの有効面積は $1,930 \mathrm{~mm}^{2} \times 10$ 個 であるから，捕獲効率は $11.2 \%$ である.さらにレクテナ効率 が約 $20 \%$ （出力 $2.4 \mathrm{~mW}$ 時）であり, 総合的には $0.74 \%$ と 計算される。記の測定結果と比較して妥当な值であると 考えられる。実際には, ガウシアンビーム中心がレクテナ 配置中心より前方に位置したこと（追尾された位置はパイ ロット信号アンテナの位置) やレクテナを並列接続する際 の損失, またアンテナのヨー角依存性のばらつきなどの影 響で幾分低下しているものと考えられる.

\section{4. ま と め}

マイクロ波無線給電システムを構築し, 旋回している小型 飛行体モデルに対して自動追尾を行いながら, アクティブフ エーズドアレイを用いてマイクロ波ビームを指向させ, $4.0 \mathrm{~W}$ の電力を無線で供給するデモンストレーションを行った.

フェルト材を基板として用いた軽量フレキシブルレクテ
ナ 10 素子を搭載した MAV モデルを, 高度 $1,500 \mathrm{~mm}$, 半 径 $237 \mathrm{~mm}$ で旋回させ，モデルに搭載した小型モー夕を駆 動させることに成功した。

同実験条件で, $10 \Omega$ の負荷抵抗を用いて受電電力を測定 した結果, MAV モデルには平均 $17.6 \mathrm{~mW}$, 最大 $24 \mathrm{~mW}$ の電力を供給できていることがわかった。すすなわち, 総合 伝送効率は最大で $0.60 \%$, 平均で $0.44 \%$ であった.

効率は決して高くないが，バッテリなしでモータが駆動 できる点が重要で, 将来の移動小型ロボットの駆動方法と して, 無線電力供給の可能性を示すことができた.

\section{参 考 文 献}

1) Glaser, P. E.: Power from the Sun: Its Future, Science, 162 (1968), pp. 857-861.

2) 松本 紘, 篠原真毅: 宇宙太陽発電所とマイクロ波エネルギー伝 送技術，信学技報, SAT95-77, MW95-119, 1995, pp. 31-36.

3) 篠原真毅, 松本 紘: マイクロ波を用いた電気自動車無線充電に 関する研究, 信学論誌 C, J87-C (2004), pp. 433-443.

4) Lafleur, J. M. and Saleh, J. H.: System-Level Feasibility Assessment of Microwave Power Beaming for Small Satellites, J. Propul. Power, 25 (2009), pp. 976-983.

5) Shibata, T., Aoki, Y., Otuka, M., Idogaki, T. and Hattori, T.: Micowave Energy Transmission System for Microrobot, IEICE Trans. Electron, E80-C (1997), pp. 303-308.

6) 小紫公也：エネルギーハーベスティング技術の最新動向, シーエ ムシー出版, 東京, 2010, pp. 40-48.

7) Komatsu, S., Katsunaga, K., Ozawa, R., Komurasaki, K. and Arakawa, Y.: Power Transmission to a Micro Aerial Vehicle, AIAA Paper 2007-1003, 2007.

8) 古田島博, 川村京太郎 : 金属グリッド形サーキュラライザの設計, 信学技報, SST98-69, MW98-195, 1999, pp. 87-92. 